\title{
Shewanella pneumatophori sp. nov., an eicosapentaenoic acid-producing marine bacterium isolated from the intestines of Pacific mackerel (Pneumatophorus japonicus)
}

\author{
Kikue Hirota, ${ }^{1}$ Yoshinobu Nodasaka, ${ }^{2}$ Yoshitake Orikasa, ${ }^{3}$ \\ Hidetoshi Okuyama ${ }^{3}$ and Isao Yumoto ${ }^{1,4}$
}

Correspondence Isao Yumoto i.yumoto@aist.go.jp

\author{
${ }^{1}$ Research Institute of Genome-based Biofactory, National Institute of Advanced Industrial \\ Science and Technology (AIST), Tsukisamu-Higashi, Toyohira-ku, Sapporo 062-8517, Japan \\ ${ }^{2}$ Laboratory of Electron Microscopy, Graduate School of Dentistry, Hokkaido University, Kita-ku, \\ Sapporo 060-8586, Japan \\ ${ }^{3}$ Laboratory of Environmental Molecular Biology, Graduate School of Environmental Earth \\ Science, Hokkaido University, Kita-ku, Sapporo 060-0810, Japan \\ ${ }^{4}$ Graduate School of Agriculture, Hokkaido University, Kita-ku, Sapporo 060-8589, Japan
}

\begin{abstract}
An eicosapentaenoic acid-producing bacterium, previously described as Shewanella sp. strain SCRC-2738, was classified by phenotypic characterization, chemotaxonomic analysis, 16S rRNA gene sequence analysis and DNA-DNA hybridization. The isolate was Gram-negative, rod-shaped and motile by using polar flagella. The strain grew at $4-32{ }^{\circ} \mathrm{C}$; the optimum growth temperature was $27^{\circ} \mathrm{C}$. NaCl was required for growth. The major isoprenoid quinones were ubiquinone-7 and ubiquinone-8 and its DNA G+C content was $42.8 \mathrm{~mol} \%$. The whole-cell fatty acids mainly (above $5 \%$ ) consisted of iso- $\mathrm{C}_{13: 0}$, iso- $\mathrm{C}_{15: 0}, \mathrm{C}_{16: 0}, \mathrm{C}_{16: 1} \omega 7 c, \mathrm{C}_{18: 1} \omega 7 c$ and $\mathrm{C}_{20: 5} \omega 3$ (eicosapentaenoic acid). Phylogenetic analysis based on the 16S rRNA gene sequence showed that strain SCRC-2738 ${ }^{\top}$ was related closely (sequence similarities above $99 \%$ ) to Shewanella marinintestina (99.3\%), Shewanella sairae (99.3\%) and Shewanella schlegeliana (99.2\%). DNA-DNA hybridization and phenotypic characteristics confirmed that strain SCRC-2738 ${ }^{\top}$ merited classification as a novel species of the genus Shewanella, for which the name Shewanella pneumatophori sp. nov. is proposed. The type strain is SCRC-2738 $\left(=\mathrm{JCM} 13187^{\top}=\mathrm{NCIMB} 14060^{\top}\right)$.
\end{abstract}

Eicosapentaenoic acid (EPA) and docosahexaenoic acid (DHA) are kinds of polyunsaturated fatty acid (PUFA) present in fish, e.g. tuna, mackerel and sardines. Such PUFAs exhibit physiological and pharmacological effects (Terano et al., 1984; Harris, 1989; Abbey et al., 1990; Radwan, 1991) and are commercially very important as additives in food, cosmetics and products of the health industries (UauyDagach \& Valenzuela, 1992). In most cases, the main source of commercially available EPA and DHA is fish. However, several problems exist in terms of their production from fish, such as difficulty in obtaining highly pure products

Published online ahead of print on 24 June 2005 as DOI 10.1099/ ijs.0.63804-0.

Abbreviations: DHA, docosahexaenoic acid; EPA, eicosapentaenoic acid; PUFA, polyunsaturated fatty acid.

The GenBank/EMBL/DDBJ accession number for the 16S rRNA gene sequence of strain SCRC- $2738^{\top}$ is AB204519. and an unpleasant smell. Several strains belonging to the genus Shewanella have been reported as being high-level PUFA-producing micro-organisms. Besides these, strains belonging to the genera Colwellia, Photobacterium, Flexibacter, Vibrio and Moritella are also PUFA-producing micro-organisms (Bowman et al., 1998; Russell \& Nichols, 1999; Allen \& Bartlett, 2002). Some of these strains produce such PUFAs in relation to their piezophilic or psychrophilic natures (Yano et al., 1997; Russell \& Nichols, 1999).

In 1988, Yazawa et al. (1988a, b) first discovered two bacterial strains, from fish intestines, able to produce EPA; the strains were tentatively identified as Alteromonas spp. One of the two strains, named Alteromonas sp. SCRC-2738 (Yazawa et al., 1988a), was isolated from Pacific mackerel, Pneumatophorus japonicus. This strain produces $36 \cdot 3 \%$ EPA with respect to the total fatty acid content under appropriate culture conditions. The strain was renamed Shewanella sp. SCRC-2738 concomitant with the dissociation of the genus 
Shewanella from the genus Alteromonas (MacDonell \& Colwell, 1985). The $38 \mathrm{~kb}$ EPA-synthesis gene cluster was first isolated from strain SCRC-2738 (Yazawa, 1996). This gene cluster transformed Escherichia coli cells, enabling them to synthesize significant amounts of EPA. The gene cluster consisted of five open reading frames as essential components of EPA production. The function of these gene clusters has also been examined (Orikasa et al., 2004). Although, as described above, strain SCRC-2738 is very important in studies on bacterial EPA production, it has not been identified to species level. In the present study, taxonomic studies of strain SCRC-2738 were performed.

Shewanella sp. SCRC-2738 was obtained from the Sagami Chemical Research Center (Sagamihara, Kanagawa Prefecture, Japan). The micro-organism was cultivated until the late-exponential phase of growth by reciprocal shaking (140 r.p.m.) at $27^{\circ} \mathrm{C}$ in marine broth 2261 (Difco), for chemotaxomomic studies, or for $1-2$ days at $27^{\circ} \mathrm{C}$ in marine agar 2216 (Difco), for preparation of inoculum and maintenance of the culture. In addition to strain SCRC2738, Shewanella fidelis ATCC BAA- $318^{\mathrm{T}}$, Shewanella sairae JCM $11563^{\mathrm{T}}$, Shewanella marinintestina JCM $11558^{\mathrm{T}}$ and Shewanella schlegeliana JCM $11561^{\mathrm{T}}$ were used as reference strains for DNA-DNA hybridization. These microorganims were cultivated in marine broth 2216 by reciprocal shaking (140 r.p.m.) at $20^{\circ} \mathrm{C}$.

For morphological and phenotypic characterization, marine broth 2216 was used as the basal medium for aerobic cultivation. Samples for transmission electron microscopy were prepared and observed as described previously (Yumoto et al., 2001), using an H-800 Hitachi microscope. The culture was incubated at $27^{\circ} \mathrm{C}$ for 2 weeks and experiments were performed three times to confirm the reproducibility of the results. Carbohydrate metabolism was tested for according to the method of Leifson (1963). The results were checked daily for 2 weeks after inoculation. The hydrolysis of macromolecular substances, the test for various substrates as sole sources of carbon and energy and determination of the growth temperature were performed as described previously (Kawasaki et al., 2002; Yumoto et al., 2003). Other morphological, physiological and biochemical tests were performed as described by Barrow \& Feltham (1993). The results obtained for the morphological, physiological and biochemical characteristics of strain SCRC-2738 are given in the species description.

Cells for chemotaxonomic analysis were prepared by using cultivation in marine broth 2216 with reciprocal shaking (140 r.p.m.) at $27^{\circ} \mathrm{C}$. Whole-cell fatty acids and isoprenoid quinones were analysed as described previously (Yumoto et al., 2001). GLC analysis (with GC-353 apparatus; GL Science) revealed that the cellular fatty acid composition of strain SCRC-2738 was as follows (means of two datasets obtained from two independent samples): $\mathrm{C}_{12: 0}(4 \cdot 3 \%)$, iso- $\mathrm{C}_{13: 0}(5 \cdot 4 \%), \mathrm{C}_{14: 0}(3 \cdot 5 \%)$, iso- $\mathrm{C}_{15: 0}(8 \cdot 3 \%)$, anteiso$\mathrm{C}_{15: 0}(1 \cdot 3 \%), \mathrm{C}_{15: 0}(0 \cdot 5 \%), \mathrm{C}_{16: 0}(19 \cdot 9 \%), \mathrm{C}_{16: 1} \omega 9 \mathrm{c}$ $(1 \cdot 3 \%), \mathrm{C}_{16: 1} \omega 7 c(27 \cdot 7 \%), \mathrm{C}_{17: 1}(0 \cdot 9 \%), \mathrm{C}_{18: 0}(0 \cdot 9 \%)$,
$\mathrm{C}_{18: 1} \omega 9 c(3 \cdot 1 \%), \mathrm{C}_{18: 1} \omega 7 c(10 \cdot 0 \%), \mathrm{C}_{18: 1} \omega 11 c(0 \cdot 8 \%)$, $\mathrm{C}_{20: 4}(0 \cdot 8 \%), \mathrm{C}_{20: 5} \omega 3(\mathrm{EPA})(9 \cdot 5 \%)$ and others $(1 \cdot 8 \%)$. The fatty acid composition of strain SCRC-2738 was similar to those of S. marinintestina, S. schlegeliana, S. sairae (Satomi et al., 2003) and Shewanella gelidimarina (Bowman et al., 1997). Yazawa et al. (1988a) reported that strain SCRC-2738 produces $27 \cdot 8-36 \cdot 6 \%$ EPA with respect to the total fatty acid content. The difference between that value and the EPA content determined in the present study may due to differences in the medium and culture conditions used. The major isoprenoid quinones detected were ubiquinone- 7 and ubiquinone- 8 .

Bacterial DNA was prepared according to the method of Marmur (1961). The DNA G +C content was determined by using the method of Tamaoka \& Komagata (1984) and was found to be $42 \cdot 8 \mathrm{~mol} \%$.

The 16S rRNA gene was amplified by using the PCR method with primers 9F (5'-GAGTTTGATCCTGGCTCAG- $\left.3^{\prime}\right)$ and 1541R ( $5^{\prime}$-AAGGAGGTGATCCAGCC- $\left.3^{\prime}\right)$. The PCR product, approximately $1.5 \mathrm{~kb}$ in size, was sequenced by the dideoxynucleotide chain-termination method, using a BigDye terminator cycle sequencing kit (Applied Biosystems) and a DNA sequencer (ABI Prism 3100). Primers 9F, 339F, 785F, 1224R and 357R were used in the genesequencing reaction. Multiple alignments of the sequences were performed and the nucleotide-substitution rate $\left(K_{\text {nuc }}\right.$ value) was calculated. A phylogenetic tree was constructed by the neighbour-joining method (Kimura, 1980; Saitou \& Nei, 1987) using the CLUSTAL W program (Thompson et al., 1994). Sequence similarity was calculated by using the GENETYX computer program (Software Development). The phylogenetic position, based on the determined sequence of strain SCRC-2738 and comparison with sequences in nucleotide databases, indicated that strain SCRC-2738 belonged to the genus Shewanella. Strain SCRC-2738 was found to have highest levels of similarity with S. fidelis ATCC BAA $-318^{\mathrm{T}}(98 \cdot 5 \%)$, S. schlegeliana JCM $11561^{\mathrm{T}}(99 \cdot 2 \%)$, S. sairae JCM $11563^{\mathrm{T}}(99 \cdot 3 \%)$ and S. marinintestina JCM $11558^{\mathrm{T}}(99 \cdot 3 \%)$ (Fig. 1). These strains (with the exception of S. fidelis ATCC BAA-318 ${ }^{\mathrm{T}}$ ) produce large amounts of EPA.

The results of the 16S rRNA gene sequence analysis showed that strain SCRC-2738 is related closely to S. fidelis ATCC BAA- $318^{\mathrm{T}}$, S. schlegeliana JCM $11561^{\mathrm{T}}$, S. sairae JCM $11563^{\mathrm{T}}$ and S. marinintestina JCM $11558^{\mathrm{T}}$. These strains were used as reference strains for DNA-DNA hybridization. The level of DNA-DNA relatedness was determined fluorometrically by the method of Ezaki et al. (1989), using photobiotin-labelled DNA probes (Photoprobe biotin; Vector Laboratories) and black microplates (F16 Black Maxisorp; Nage Nunc International). The DNA-DNA hybridization results indicate that strain SCRC-2738 belongs to a species distinct from $S$. fidelis ATCC BAA$318^{\mathrm{T}}$ (37·1 \% DNA-DNA relatedness), S. schlegeliana JCM $11561^{\mathrm{T}}(38 \cdot 7 \%)$, S. sairae JCM $11563^{\mathrm{T}}(13 \cdot 9 \%)$ and $S$. marinintestina JCM $11558^{\mathrm{T}}(8 \cdot 1 \%)$. These values were reproducible. Strain SCRC-2738 was thus confirmed to 


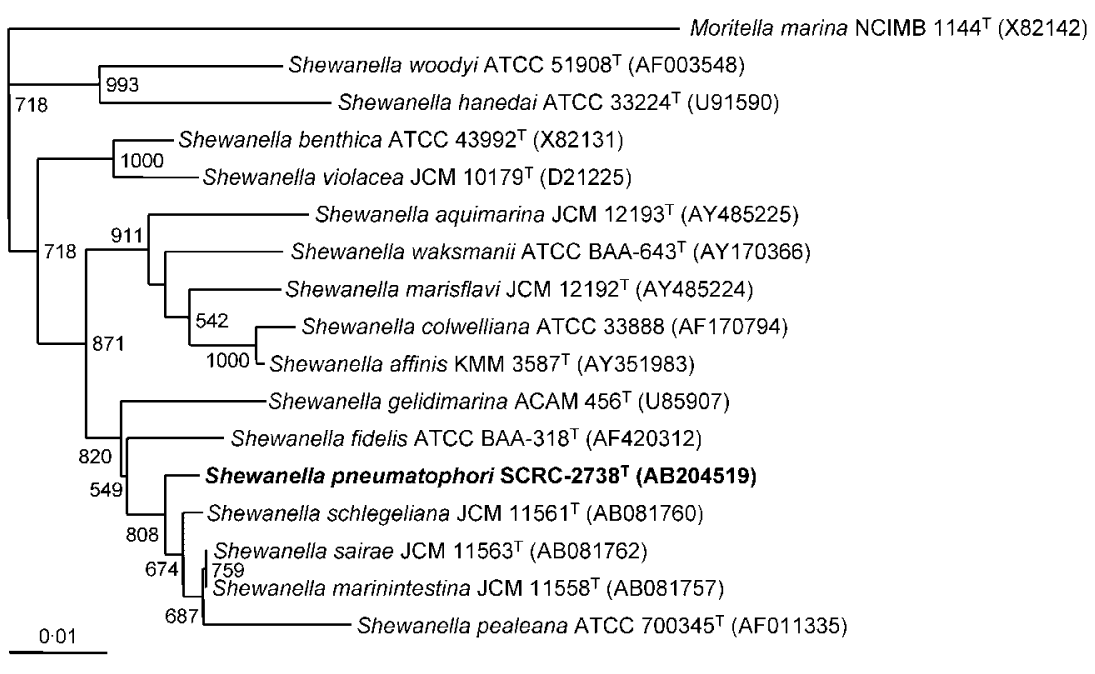

Fig. 1. Phylogenetic tree derived from $16 \mathrm{~S}$ rRNA gene sequence data of $S$. pneumatophori strain SCRC- $2738^{\top}$ and other related organisms by using the neighbour-joining method. Bootstrap values greater than 500 from 1000 replications are shown at branching points. Bar, $0.01 K_{\text {nuc }}$. belong to a species different from other phylogenetically related Shewanella strains.

Strain SCRC-2738 differed phenotypically and chemotaxonomically from phylogenetically closely related species and from other Shewanella strains, as shown in Table 1.

The growth characteristics and EPA production of strain SCRC-2738 were different from those of S. fidelis. Although strain SCRC-2738 exhibited very high levels of similarity with S. schlegeliana JCM $11561^{\mathrm{T}}$, S. sairae JCM $11563^{\mathrm{T}}$ and S. marinintestina JCM $11558^{\mathrm{T}}$ in terms of $16 \mathrm{~S}$ rRNA gene sequence, there were obvious differences in growth characteristics, the fermentation of D-glucose (Table 1), colony colour and nitrate reduction to nitrite (Satomi et al., 2003).

On the basis of the above results, strain SCRC-2738 was designated to belong to a novel species of the genus Shewanella, for which the name Shewanella pneumatophori sp. nov. is proposed; the type strain is SCRC- $2738^{\mathrm{T}}$.

Table 1. Characteristics of $S$. pneumatophori sp. nov. and related species

Species: 1, S. pneumatophori sp. nov.; 2, S. fidelis (Ivanova et al., 2003); 3, S. schlegeliana (Satomi et al., 2003); 4, S. sairae (Satomi et al., 2003); 5, S. marinintestina (Satomi et al., 2003); 6, Shewanella pealeana (Leonardo et al., 1999; Satomi et al., 2003); 7, S. gelidimarina (Bowman et al., 1997); 8, Shewanella olleyana (Skerratt et al., 2002); 9, Shewanella colwelliana (Weiner et al., 1988); 10, Shewanella hanedai (Baumann et al., 1984); 11, Shewanella woodyi (Makemson et al., 1997); 12, Shewanella frigidimarina (Bozal et al., 2002); 13, Shewanella japonica (Ivanova et al., 2001). +, Positive; -, negative; ND, no data.

\begin{tabular}{|c|c|c|c|c|c|c|c|c|c|c|c|c|c|}
\hline Characteristic & 1 & 2 & 3 & 4 & 5 & 6 & 7 & 8 & 9 & 10 & 11 & 12 & 13 \\
\hline \multicolumn{14}{|l|}{ Growth at: } \\
\hline $25^{\circ} \mathrm{C}$ & + & + & + & + & + & + & - & + & + & + & + & + & + \\
\hline $37^{\circ} \mathrm{C}$ & - & - & - & - & - & - & - & - & - & - & - & - & + \\
\hline Optimum growth temp. $\left({ }^{\circ} \mathrm{C}\right)$ & 27 & $20-25$ & $20-25$ & $20-25$ & $20-25$ & 25 & $15-17$ & $20-22$ & 25 & $15-20$ & 25 & $20-22$ & $20-25$ \\
\hline \multicolumn{14}{|l|}{ Growth in $\mathrm{NaCl}$ at: } \\
\hline $6 \%$ & + & + & - & - & - & - & + & + & - & - & - & + & - \\
\hline Fermentation of D-glucose & + & + & - & - & - & - & - & - & - & - & - & + & + \\
\hline Utilization of D-glucose & + & + & + & + & + & + & - & - & - & - & - & + & + \\
\hline EPA production & + & - & + & + & + & + & + & + & $\mathrm{ND}$ & + & + & + & + \\
\hline \multicolumn{14}{|l|}{ Hydrolysis of: } \\
\hline DNA G $+\mathrm{C}$ content $(\mathrm{mol} \%)$ & 43 & 45 & 45 & 43 & 43 & 45 & 48 & 44 & 46 & 45 & 39 & $40-43$ & $43-44$ \\
\hline
\end{tabular}




\section{Description of Shewanella pneumatophori sp. nov.}

Shewanella pneumatophori (pneu.ma.to.pho'ri. N.L. gen. n. pneumatophori of Pneumatophorus japonicus, the scientific name of the Pacific mackerel).

Cells are rod-shaped $(0.4-0.6 \times 1.4-4.6 \mu \mathrm{m})$, Gramnegative and have polar flagella. Colonies are circular with entire margins and are slightly pinkish. Catalase and oxidase reactions are positive. Growth occurs in the presence of $1-8 \% \mathrm{NaCl}$. Growth occurs at $4-32{ }^{\circ} \mathrm{C}$ (optimum, $27^{\circ} \mathrm{C}$ ). The organism is positive for $\mathrm{H}_{2} \mathrm{~S}$ production, but negative results are obtained in methyl red, Voges-Proskauer and ONPG tests, for nitrate reduction to nitrite and for indole production. Hydrolyses casein, gelatin, DNA and Tweens 20, 40, 60 and 80, but not chitin, starch, aesculin or hippurate. Acid is not produced oxidatively from L-arabinose, D-fructose, D-maltose, D-mannose, melibiose, sucrose, Dxylose, raffinose, myo-inositol, mannitol, sorbitol, Dgalactose, L-rhamnose, trehalose, lactose or glycerol. Acid is produced from D-glucose, D-fructose and D-galactose under anaerobic conditions. Utilizes D-glucose as sole carbon source, but not L-arabinose, D-fructose, D-maltose, D-mannose, melibiose, sucrose, D-xylose, raffinose, myoinositol, mannitol, sorbitol, D-galactose, L-rhamnose, cellobiose, trehalose, lactose or glycerol. The major isoprenoid quinones are ubiquinone-7 and ubiquinone-8. The major (above $5 \%$ ) fatty acids are iso- $\mathrm{C}_{13: 0}$, iso- $\mathrm{C}_{15: 0}, \mathrm{C}_{16: 0}$, $\mathrm{C}_{16: 1} \omega 9 c$ and $\mathrm{C}_{20: 5} \omega 3$ (EPA). The DNA G+C content is $42 \cdot 8 \mathrm{~mol} \%$.

The type strain, SCRC- $2738^{\mathrm{T}}\left(=\mathrm{JCM} 13187^{\mathrm{T}}=\mathrm{NCIMB}\right.$ $14060^{\mathrm{T}}$ ), was isolated from the intestines of Pacific mackerel (Pneumatophorus japonicus).

\section{References}

Abbey, M., Clifton, P., Kestin, M., Belling, B. \& Nestel, P. (1990). Effect of fish oil on lipoproteins, lecithin: cholesterol acyltransferase, and lipid transfer protein activity in humans. Arteriosclerosis 10, 85-94.

Allen, E. E. \& Bartlett, D. H. (2002). Structure and regulation of the omega-3 polyunsaturated fatty acid synthase genes from the deep-sea bacterium Photobacterium profundum strain SS9. Microbiology 148, 1903-1913.

Barrow, G. I. \& Feltham, R. K. A. (editors) (1993). Cowan and Steel's Manual for the Identification of Medical Bacteria, 3rd edn. Cambridge: Cambridge University Press.

Baumann, P., Gauthier, M. J. \& Baumann, L. (1984). Genus Alteromonas Baumann, Baumann, Mandel and Allen 1972, $418^{\mathrm{AL}}$. In Bergey's Manual of Systematic Bacteriology, vol. 1, pp. 343-352. Edited by N. R. Krieg \& J. G. Holt. Baltimore: Williams \& Wilkins.

Bowman, J. P., McCammon, S. A., Nichols, D. S., Skerratt, J. H., Rea, S. M., Nichols, P. D. \& McMeekin, T. A. (1997). Shewanella gelidimarina sp. nov. and Shewnella frigidimarina sp. nov., novel Antactic species with the ability to produce eicosapentaenoic acid $(20: 5 \omega 3)$ and grow anaerobically by dissimilatory $\mathrm{Fe}(\mathrm{III})$ reduction. Int J Syst Bacteriol 47, 1040-1047.
Bowman, J. P., Gosink, J. J., McCammon, S. A., Lewis, T. E., Nichols, D. S., Nichols, P. D., Skerratt, J. H., Staley, J. T. \& McMeekin, T. A. (1998). Colwellia demingiae sp. nov., Colwellia hornerae sp. nov., Colwellia rossensis sp. nov. and Colwellia psychrotropica sp. nov.: psychrophilic Antarctic species with the ability to synthesize

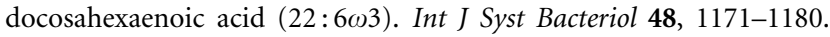

Bozal, N., Montes, M. J., Tudela, E., Jiménez, F. \& Guinea, J. (2002). Shewanella frigidimarina and Shewanella livingstonensis sp. nov. isolated from Antarctic coastal areas. Int J Syst Evol Microbiol 52, 195-205.

Ezaki, T., Hashimoto, Y. \& Yabuuchi, E. (1989). Fluorometric deoxyribonucleic acid-deoxyribonucleic acid hybridization in microdilution wells as an alternative to membrane filter hybridization in which radioisotopes are used to determine genetic relatedness among bacterial strains. Int J Syst Bacteriol 39, 224-229.

Harris, W. S. (1989). Fish oils and plasma lipid and lipoprotein metabolism in humans: a critical review. J Lipid Res 30, 785-807.

Ivanova, E. P., Sawabe, T., Gorshkova, N. M., Svetashev, V. I., Mikhailov, V. V., Nicolau, D. V. \& Christen, R. (2001). Shewanella japonica sp. nov. Int J Syst Evol Microbiol 51, 1027-1033.

Ivanova, E. P., Sawabe, T., Hayashi, K., Gorshkova, N. M., Zhukova, N. V., Nedashkovskaya, O. I., Mikhailov, V. V., Nicolau, D. V. \& Christen, R. (2003). Shewanella fidelis sp. nov., isolated from sediments and sea water. Int J Syst Evol Microbiol 53, 577-582.

Kawasaki, K., Nogi, Y., Hishinuma, M., Nodasaka, Y., Matsuyama, H. \& Yumoto, I. (2002). Psychromonas marina sp. nov., a novel halophilic, facultatively psychrophilic bacterium isolated from the coast of the Okhotsk Sea. Int J Syst Evol Microbiol 52, 1455-1459.

Kimura, M. (1980). A simple method for estimating evolutionary rates of base substitutions through comparative studies of nucleotide sequences. J Mol Evol 16, 111-120.

Leifson, E. (1963). Determination of carbohydrate metabolism of marine bacteria. J Bacteriol 85, 1183-1184.

Leonardo, M. R., Moser, D. P., Barbieri, E., Brantner, C. A., MacGregor, B. J., Paster, B. J., Stackebrandt, E. \& Nealson, K. H. (1999). Shewanella pealeana sp. nov., a member of the microbial community associated with the accessory nidamental gland of the squid Loligo pealei. Int J Syst Bacteriol 49, 1341-1351.

MacDonell, M. T. \& Colwell, R. R. (1985). Phylogeny of the Vibrionaceae, and recommendation for two new genera, Listonella and Shewanella. Syst Appl Microbiol 6, 171-182.

Makemson, J. C., Fulayfil, N. R., Landry, W., Van Ert, L. M., Wimpee, C. F., Widder, E. A. \& Case, J. F. (1997). Shewanella woodyi sp. nov., an exclusively respiratory luminous bacterium isolated from the Alboran Sea. Int J Syst Bacteriol 47, 1034-1039.

Marmur, J. (1961). A procedure for the isolation of deoxyribonucleic acid from microorganisms. J Mol Biol 3, 208-218.

Orikasa, Y., Yamada, A., Yu, R., Ito, Y., Nishida, T., Yumoto, I., Watanabe, K. \& Okuyama, H. (2004). Characterization of the eicosapentaenoic acid biosynthesis gene cluster from Shewanella sp. strain SCRC-2738. Cell Mol Biol 50, 625-630.

Radwan, S. S. (1991). Sources of C20-polyunsaturated fatty acids for biotechnological use. Appl Microbiol Biotechnol 35, 421-430.

Russell, N. J. \& Nichols, D. S. (1999). Polyunsaturated fatty acids in marine bacteria - a dogma rewritten. Microbiology 145, 767-779.

Saitou, N. \& Nei, M. (1987). The neighbor-joining method: a new method for reconstructing phylogenetic trees. Mol Biol Evol 4, 406-425.

Satomi, M., Oikawa, H. \& Yano, Y. (2003). Shewanella marinintestina sp. nov., Shewanella schlegeliana sp. nov. and Shewanella sairae sp. nov., novel eicosapentaenoic-acid-producing marine bacteria 
isolated from sea-animal intestines. Int J Syst Evol Microbiol 53, 491-499.

Skerratt, J. H., Bowman, J. P. \& Nichols, P. D. (2002). Shewanella olleyana sp. nov., a marine species isolated from a temperate estuary which produces high levels of polyunsaturated fatty acids. Int J Syst Evol Microbiol 52, 2101-2106.

Tamaoka, J. \& Komagata, K. (1984). Determination of DNA base composition by reverse-phase high-performance liquid chromatography. FEMS Microbiol Lett 25, 125-128.

Terano, T., Salmon, J. A. \& Moncada, S. (1984). Biosynthesis and biological activity of leukotriene $\mathrm{B}_{5}$. Prostaglandins 27, 217-232.

Thompson, J. D., Higgins, D. G. \& Gibson, T. J. (1994). CLUSTAL W: improving the sensitivity of progressive multiple sequence alignment through sequence weighting, position-specific gap penalties and weight matrix choice. Nucleic Acids Res 22, 4673-4680.

Uauy-Dagach, R. \& Valenzuela, A. (1992). Marine oils as a source of omega-3 fatty acids in the diet: how to optimize the health benefits. Prog Nutr Food Sci 16, 199-243.

Weiner, R. M., Coyne, V. E., Brayton, P., West, P. \& Raiken, S. F. (1988). Alteromonas colwelliana sp. nov., an isolate from oyster habitats. Int J Syst Bacteriol 38, 240-244.
Yano, Y., Nakayama, A. \& Yoshida, K. (1997). Distribution of polyunsaturated fatty acids in bacteria present in intestines of deep-sea fish and shallow-sea poikilothermic animals. Appl Environ Microbiol 63, 2572-2577.

Yazawa, K. (1996). Production of eicosapentaenoic acid from marine bacteria. Lipids 31 (Suppl.), S297-S300.

Yazawa, K., Araki, K., Okazaki, N., Watanabe, K., Ishikawa, C., Inoue, A., Numao, N. \& Kondo, K. (1988a). Production of eicosapentaenoic acid by marine bacteria. J Biochem 103, 5-7.

Yazawa, K., Araki, K., Watanabe, K., Ishikawa, C., Inoue, A., Kondo, K., Watabe, S. \& Hashimoto, K. (1988b). Eicosapentaenoic acid productivity of the bacteria isolated from fish intestines. Nippon Suisan Gakkaishi 54, 1835-1838.

Yumoto, I., Yamazaki, K., Hishinuma, M., Nodasaka, Y., Suemori, A., Nakajima, K., Inoue, N. \& Kawasaki, K. (2001). Pseudomonas alcaliphila sp. nov., a novel facultatively psychrophilic alkaliphile isolated from seawater. Int J Syst Evol Microbiol 51, 349-355.

Yumoto, I., Hirota, K., Sogabe, Y., Nodasaka, Y., Yokota, Y. \& Hoshino, T. (2003). Psychrobacter okhotskensis sp. nov., a lipaseproducing facultative psychrophile isolated from the coast of the Okhotsk Sea. Int J Syst Evol Microbiol 53, 1985-1989. 